\title{
ResearchArticle
}

\section{Effect of plant and row spacing on growth and yield of onion under Mokokchung district of Nagaland}

\author{
RENBOMO NGULLIE AND PIJUSH KANTI BISWAS
}

\section{SUMMARY}

The experiment was undertaken to determine the effect of different plant and row spacing on growth and yield of onion. 8 different spacings were taken viz., $20 \times 10 \mathrm{~cm}, 20 \times 15 \mathrm{~cm}, 20 \times 20 \mathrm{~cm}, 25 \times 10 \mathrm{~cm}, 25 \times 15 \mathrm{~cm}, 25 \times 20 \mathrm{~cm}, 30 \times 10$ and $30 \times 15 \mathrm{~cm}$. Variety Nasik Red was used for the study. The results demonstrated that plant spacing had significant effects on growth, yield components and yield of onion. Significantly wider spacing produced higher size of plant height, leaf length and number of leaves. Bulb diameter, circumference and weight also have the same trend in wider spacing. The weight of individual onion bulb $(53.0 \mathrm{~g})$ was increased with the widest spacing of $30 \mathrm{x} 15 \mathrm{~cm}$. On the contrary, the overall yield/ha was the highest $(17.69 \mathrm{t} / \mathrm{ha})$ at the closest spacing $(20 \mathrm{x} 10 \mathrm{~cm})$ and the lowest $(9.51 \mathrm{t} / \mathrm{ha})$ was at widest spacing $(30 \mathrm{x} 15 \mathrm{~cm})$.

Key Words : Onion, Spacing, Growth, Yield How to cite this article : Ngullie, Renbomo and Biswas, Pijush Kanti (2017). Effect of plant and row spacing on growth and yield of
onion under Mokokchung district of Nagaland. Internat. J. Plant Sci., 12 (1): 28-35, DOI: 10.15740/HAS/IJPS/12.1/28-35.

Article chronicle : Received : 06.07.2016; Revised : 11.11.2016; Accepted : 07.12.2016

\section{MEMBERS OF THE RESEARCH FORUM}

Author to be contacted :

PIJUSH KANTI BISWAS, Krishi Vigyan Kendra, Yisemyong, MOKOKCHUNG (NAGALAND) INDIA

Email: drpijushpckvk@gmail.com

Address of the Co-authors:

RENBOMO NGULLIE, Krishi Vigyan Kendra, Yisemyong,

MOKOKCHUNG (NAGALAND) INDIA 